\title{
Phytochemical screening, invitro antioxidant and anti-inflammatory activity of polyphenolic fraction extracted from Camellia sinensis bud extract
}

\author{
J. Divyabharathi ${ }^{1^{*}}$, Dr. D. Chandra Prabha ${ }^{2}$, Dr.R. Ragunathan ${ }^{3}$ \\ 1-MPhil research Scholar,2- Associate professor, Department of Biochemistry, Sri \\ Ramakrishna College of Arts and Science for Women, Coimbatore \\ 3- Director and research supervisor of Centre for Bioscience and Nanotechnology Research, \\ Coimbatore
}

\begin{abstract}
Tea is one of the most widely consumed beverages in the world today, second only to water, well ahead of coffee, beer, wine and carbonated soft drinks. The tea plant, Camellia sinensis, is a member of the Theaceae family and black, oolong, white and green tea are produced from its leaf and buds. Tea beverage is an infusion of the dried leaves of Camellia sinensis. The present study aims to screen the phytochemicals screening, in vitro antioxidant and anti-inflammatory activity of polyphenolic compound extracted from Camellia sinensis bud extract. The qualitative phytochemical results revealed the presence of important phytochemicals like alkaloids, flavonoids, phenols, and tannins. The C. sinensis buds could be a rich source of antioxidants. The extract showed significant antioxidant and anti-inflammatory activity. Total phenolic content of the bud's extract was found to be
\end{abstract} $123 \mathrm{mg} / \mathrm{GAE}$. The extract possesses a significant antioxidant and anti-inflammatory activity.

Keywords

Phytochemicals, Antioxidant, Anti-inflammatory, column chromatography, Total phenolics.

Introduction

Tea is a popular nutraceutical as an antioxidant. Increasing evidence has expanded the role of white tea from a traditional beverage to a source of pharmacologically active molecules with diverse health benefits. Phytochemicals residing in plants give organoleptic properties and colour to the plant. In many places, as a dietary accessory they are comfortably approachable but dormant health advantages of phytochemicals are only reachable from the utilization of whole plant [1]. Phytochemicals are beneficial to boost up immunomodulatory responses and also provide immunity against many diseases. Some phytochemicals are known to reveal medicinal and physiological activities which are phenols, tannins, flavonoids, saponins, carbohydrates, alkaloids, phytosterols etc. [2] 
Antioxidants or inhibitors of oxidation are compounds which retard or prevent the oxidation and in general prolong the life of the oxidizable matter. Majority of the diseases/disorders are mainly linked to oxidative stress due to free radicals. The free radicals (oxidants) are species with very short half-life, high reactivity and damaging activity towards macromolecules like proteins, DNA and lipids. In general, the reactive oxygen species circulating in the body tend to react with the electron of other molecules in the body and these also effect various enzyme systems and cause damage which may further contribute to conditions such as cancer, ischemia, aging, adult respiratory distress syndromes, rheumatoid arthritis etc. [3]

Aromatic plants are widely used also as nutritional supplements. Of special interest is their value as a source of natural antioxidants. Due to increasing safety concerns involved with consumption of synthetic antioxidants, exploitation of cheaper and safer sources of antioxidants from natural origins, and especially from plants, is of interest nowadays. The major plant compounds characterized by antioxidant activity are polyphenols. The antioxidant activity of polyphenols is accredited to their redox properties [4] and anti-inflammatory activities (5).

Materials and Methods

Plant sample

The buds of Camellia sinensis was collected from the local area of Nilgiris and were authenticated by Botanical Survey of India, Southern Regional Centre, Coimbatore.

Sample preparation

The collected buds were washed and cleaned with water, then shade dried for about 15 days. The dried Camellia sinensis bud sample were crushed to coarse powder and then grinded using mortar and pestle. $10 \mathrm{~g}$ of powdered sample was suspended in $100 \mathrm{ml}$ of Hydro ethanol and kept in a shaker for about 24 hours and then filtered.

Qualitative phytochemical analysis

Test for alkaloids: To $1 \mathrm{ml}$ of the extract, add $2 \mathrm{ml}$ of Wagner's reagent (iodine in potassium iodide). The formation of reddish-brown precipitate confirms the presence of alkaloids.[6]

Test for phenols: To $1 \mathrm{ml}$ of extract added $2 \mathrm{ml}$ of distilled water followed by few drops of $10 \%$ $\mathrm{FeCl}_{3}$. The appearance of blue or black colour indicates presence of phenols. [7]

Test for Saponins: About $2 \mathrm{ml}$ of extract and $2 \mathrm{ml}$ of distilled water was added in a test tube. The mixture was shaken vigorously and observed for the formation of persistent foam for few seconds. The presence of foam confirms the presence of saponins. [6] 
Test for Flavonoids: To about $2 \mathrm{ml}$ of extract, few drops of $10 \%$ ferric chloride solution were added. The formation of green or blue colour indicates the presence of flavonoids.[8]

Test for Phytosterols: $1 \mathrm{ml}$ of the extract was treated with $2 \mathrm{ml}$ of chloroform and few drops of acetic anhydride to which equal amount of concentrated sulphuric acid was added. The formation of bluish green colour indicates the presence of phytosterols. [11]

Test for amino acids and proteins: To few $\mathrm{ml}$ of the extract added small amount of Ninhydrin reagent. After mixing it well, the solution was boiled in water bath for 2-3 minutes. A bluish or blackish colour indicated the presence of proteins. [9]

Test for steroids: To $1 \mathrm{ml}$ of extract dissolved $2 \mathrm{ml}$ chloroform and $0.2 \mathrm{ml}$ of concentrated $\mathrm{H}_{2} \mathrm{SO}_{4}$ was added. The formation of red colour precipitate indicates the presence of steroids. [7]

Test for tannin: To: $1 \mathrm{ml}$ of extract added few drops of dilute ferric chloride solution. The presence of tannin is indicated by the formation of bluish black or greenish black precipitate.[7]

Test for cardiac glycosides: To $1 \mathrm{ml}$ of plant extract added few $\mathrm{ml}$ of concentrated sulphuric acid. Formation of red colour indicates the presence of glycosides. [12]

Test for carbohydrates: To $0.5 \mathrm{ml}$ of the extract, added 4-5 drops of Benedict's reagent and heated in a boiling water bath for 5 minutes. The appearance of blue colour indicates the presence of carbohydrates. [10]

Quantitative phytochemical analysis

Determination of Total Phenol

$1.0 \mathrm{ml}$ of plant extract was added to $2 \mathrm{ml}$ of Folin - ciocalteu's reagent and $1.0 \mathrm{ml}$ of $20 \%$ Sodium carbonate solution. The mixture was incubated at $45^{\circ} \mathrm{C}$ for 45 minutes. Then absorbance of the sample was read at $765 \mathrm{~nm}$. The control was set up using $2 \mathrm{ml}$ of Folin's reagent and $1.0 \mathrm{ml}$ of Sodium carbonate solution. A calibration curve was constructed using Gallic acid dilutions as standard and total phenolic content of the extract were identified [13].

Isolation of polyphenol from hydro ethanolic bud extract

Column chromatography

A cylinder-shaped glass column $(32 \times 2.5 \mathrm{~cm})$ containing stationary phase (silica gel- $\mathrm{G})$ is added slowly from the top with a liquid solvent (mobile phase that flows down the column with the help gravity or external pressure applied. This technique is used for the purification of compounds. Once the column is ready, the sample $(40 \mathrm{ml}$ and $20 \mathrm{ml}$ of Ethanol) is loaded inside the top of the column. The mobile solvent is then allowed to flow down through the column. The compounds in mixture have different interaction's ability with stationary phase (silica gel), and mobile phase, thereby will flow 
along the mobile phase at different time intervals or degrees. In this way, the separation of compounds from the mixture is achieved. The individual compounds are collected as fractions and analysed further for structure elucidation.

A suitable size long cylindrical glass column should be stand firm on a column-chromatography stand. Hydroethanolic plant extract should be placed on the top of the pre-packed silica column and sample should be covered with a layer of cotton. Then solvents of different polarities were passed through column at uniform rate under gravity to fractionate the plant extract. Each fraction was collected separately to the capillary tubes and numbered consecutively for further analysis. [14]

\section{Invitro Antioxidant assay}

Total antioxidant activity

The total antioxidant capacity of the fractions was determined by phosphomolybdate method using ascorbic acid as a standard. An aliquot of $0.5 \mathrm{ml}$ of Camellia sinensis bud extract was mixed with $1 \mathrm{ml}$ of reagent solution $(0.6 \mathrm{M}$ sulphuric acid, $28 \mathrm{mM}$ sodium phosphate and $4 \mathrm{mM}$ ammonium molybdate). The tubes were capped and incubated in a water bath at $50^{\circ} \mathrm{C}$ for $90 \mathrm{~min}$. After the sample had cooled to room temperature, the absorbance of the mixture was measured at $695 \mathrm{~nm}$ against a blank. A typical blank contained $1 \mathrm{ml}$ of the reagent solution and the appropriate volume of the solvent and incubated under the same conditions. The antioxidant capacity was estimated using following formula. [15]

$$
\text { Percentage inhibition }=(\text { Abs Control }- \text { Abs Sample }) / \text { Abs Control } \times 100
$$

\section{DPPH assay}

The antioxidant activity of the hydroethanolic extract of Camellia sinensis were determined using 1,1 - diphenyl-2-picryl-hydrazil (DPPH). To a test tube added $0.1 \mathrm{ml}$ of DPPH reagent and $0.4 \mathrm{ml}$ of Tris HCL. This serves as a control. To $0.5 \mathrm{ml}$ plant extract, added $0.1 \mathrm{ml}$ of DPPH. Then mix well and incubate for 5 minutes at room temperature, and added $0.4 \mathrm{ml}$ of Tris HCL. The test tube was incubated in dark at room temperature for about 30minutes. The absorbance was read at $517 \mathrm{~nm}$ in a spectrophotometer and the readings were recorded. [16]

$$
\text { Percentage inhibition }=(\text { Abs Control }- \text { Abs Sample }) / \text { Abs Control } \times 100
$$

\section{Determination of reducing/antioxidant power (FRAP)}

The ferric ions $\left(\mathrm{Fe}^{+}\right)$reducing antioxidant power (FRAP) method was used to measure the reducing capacity of the plant extracts with a slight modification, which involves the presence of extracts to reduce the ferricyanide complex to the ferrous form. $1.0 \mathrm{ml}$ of Camellia sinensis bud extract from the stock solutions and the standard (ascorbic acid) were mixed with $1.0 \mathrm{ml}$ of phosphate buffer 
$(0.2 \mathrm{M}, \mathrm{pH} 6.6)$ and $1.0 \mathrm{ml}$ of potassium ferricyanide $(0.1 \% \mathrm{w} / \mathrm{v})$. The mixture was incubated at $50^{\circ} \mathrm{C}$ for $20 \mathrm{~min}$. Then $1.0 \mathrm{ml}$ of trichloroacetic acid $(10 \% \mathrm{w} / \mathrm{v})$ was added to the reaction mixture. Afterwards, it was centrifuged at 5000rpm for $10 \mathrm{~min}$. The upper layer of the solution $(1.0 \mathrm{ml})$ was mixed with distilled water $(1.0 \mathrm{ml})$ and ferric chloride $(0.5 \mathrm{ml} 0.1 \% \mathrm{w} / \mathrm{v})$. The absorbance was measured at $700 \mathrm{~nm}$ at the reaction time of $30 \mathrm{~min}$. [17]

$$
\text { Percentage inhibition }=(\text { Abs Control }- \text { Abs Sample }) / \text { Abs Control } \times 100
$$

Anti-inflammatory activity

Trypsin (Proteinase) inhibitory method

To $1 \mathrm{ml}$ of Camellia sinensis bud extract added the reaction mixture. The reaction mixture (2.0 $\mathrm{ml}$ ) contains $0.06 \mathrm{mg}$ trypsin, $1.0 \mathrm{ml} .20 \mathrm{mM}$ tris- $\mathrm{HCl}$ buffer (pH 7.4). The mixture was incubated at $37^{\circ} \mathrm{C}$ for 5 minutes, then $1.0 \mathrm{ml}$ of $0.8 \%(\mathrm{w} / \mathrm{v})$ casein was added. The mixtures were incubated for an additional 20 minutes. Then added $2.0 \mathrm{ml}$ of $70 \%(\mathrm{v} / \mathrm{v})$ perchloric acid to terminate the reaction. The cloudy suspension was centrifuged at $5000 \mathrm{rpm}$ and absorbance of the supernatant was read at $210 \mathrm{~nm}$ against blank.[18]

Percentage inhibition $=($ O.D. of control - O.D. of product test $) \times 100$ O.D. of Control Protein denaturation inhibition method

To $0.2 \mathrm{ml}$ of egg albumin added $2.8 \mathrm{ml}$ phosphate buffer. To this solution $1 \mathrm{ml}$ of the Camellia sinensis bud extract was added. For the control, distilled water was added instead of test extract. The reaction mixture was incubated at $37^{\circ} \mathrm{C}$ for 20 minutes and afterwards heated to $90^{\circ} \mathrm{C}$ for 5 minutes. The absorbance was taken at $660 \mathrm{~nm}$, after cooling. Diclofenac sodium was taken as a standard. The protein denaturation inhibition percentage was determined by following formula. [19]

Percentage inhibition $=($ O.D. of control - O.D. of test $) \times 100 /$ O.D. of Control

\section{Results and discussion}

The phytochemical analysis of hydroethanolic bud extract of Camellia sinensis revealed the presence of alkaloids, flavonoids, saponins, steroids, glycosides, phenols, tannins, phytosterols and carbohydrates

Table 1. Phytochemical analysis of C.sinensis buds extract

\begin{tabular}{|c|c|}
\hline Phytochemicals & Hydro ethanol \\
\hline Alkaloids & + \\
\hline Flavonoids & + \\
\hline Saponin & + \\
\hline
\end{tabular}




\begin{tabular}{|c|c|}
\hline Phenol & + \\
\hline Phytosterol & + \\
\hline Aminoacids \& & - \\
\hline proteins & + \\
\hline Steroids & + \\
\hline Tannin & + \\
\hline Carbohydrates & \\
\hline
\end{tabular}

$(+)=$ presence of phytochemicals $(-)=$ absence of phytochemicals

In accordance with our studies Ibrahim et al (2020) also observed the presence of alkaloids, saponins, tannins, flavonoids, phenols and sterols in methanolic extract of green tea leaves.[20]

Quantitative determination of total phenol

The determination of the amount of total phenolic content of C.sinensis bud extract was performed by the Folin Ciocalteau's method.Gallic acid was used as standard for total phenolic acid. Total phenolic content of the plant extract was $123 \mathrm{mg} / \mathrm{GAE}$ for C. sinensis.

\section{Figure 1: Total phenol}

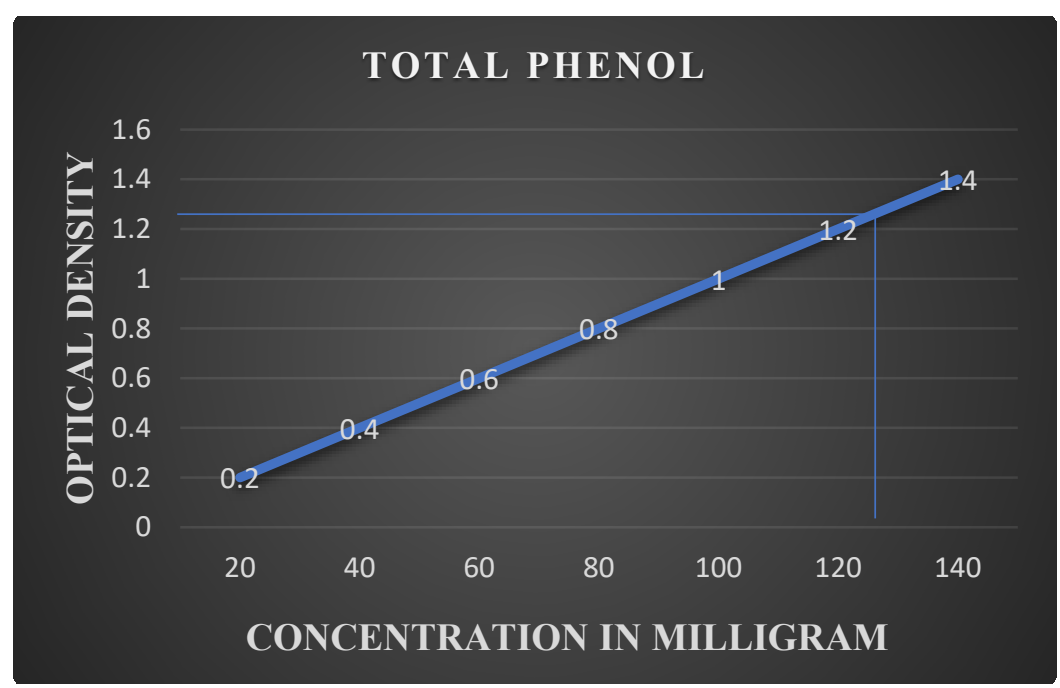

Amandeep et al.,2019 observed the total phenolic content of different types of Camellia sinensis extract white (Silver Needle), Green and Black Tea. The results exhibited the following order: white tea $(133.30 \mathrm{mg} / \mathrm{g})>$ green tea $(118.37 \mathrm{mg} / \mathrm{g})>$ black tea $(101.8 \mathrm{mg} / \mathrm{g})$. A strong correlation was observed between the total phenolic content and antioxidant activity of different types of Tea extracts. [21]

Column chromatography

The fractions obtained from silica gel -G column chromatography of Camellia sinensis bud extract was centrifuged at 5000rpm for $10 \mathrm{mins}$ and optical density values were determined using 
spectrophotometer. The phytocompounds showing the same OD values were pooled into a single fraction and used for further analysis.

Raksha et al 2017 reported that the aqueous extraction of Green Tea polyphenols was performed at three different temperatures $40^{\circ} \mathrm{C}, 50^{\circ} \mathrm{C}$ and $60^{\circ} \mathrm{C}$ and at three corresponding time 15 minutes, 30 minutes and 60 minutes and observed that maximum polyphenols content was obtained at $40^{\circ} \mathrm{C}$ for 30 minutes. (22)

Invitro anti-oxidant activity

The result of the antioxidant study of Hydroethanolic bud extract $C$. sinensis was represented in table and figure

Table 2: Antioxidant activity of $C$. sinensis bud extract

\begin{tabular}{|c|c|c|}
\hline S. No & Assays & $\begin{array}{c}\text { Concentration in } \\
\mu \mathrm{g} / \mathrm{ml}\end{array}$ \\
\hline 1 & Total antioxidant & 28 \\
\hline 2 & DPPH & 66.3 \\
\hline 3 & FRAP & 240 \\
\hline
\end{tabular}

Total antioxidant assay

The total anti-oxidant capacity of hydroethanolic bud extract of Camellia sinensis was found to be $28 \mu \mathrm{g} / \mathrm{g}$ at a concentration of $500 \mu \mathrm{g} / \mathrm{ml}$.

Figure 2: Total antioxidant assay

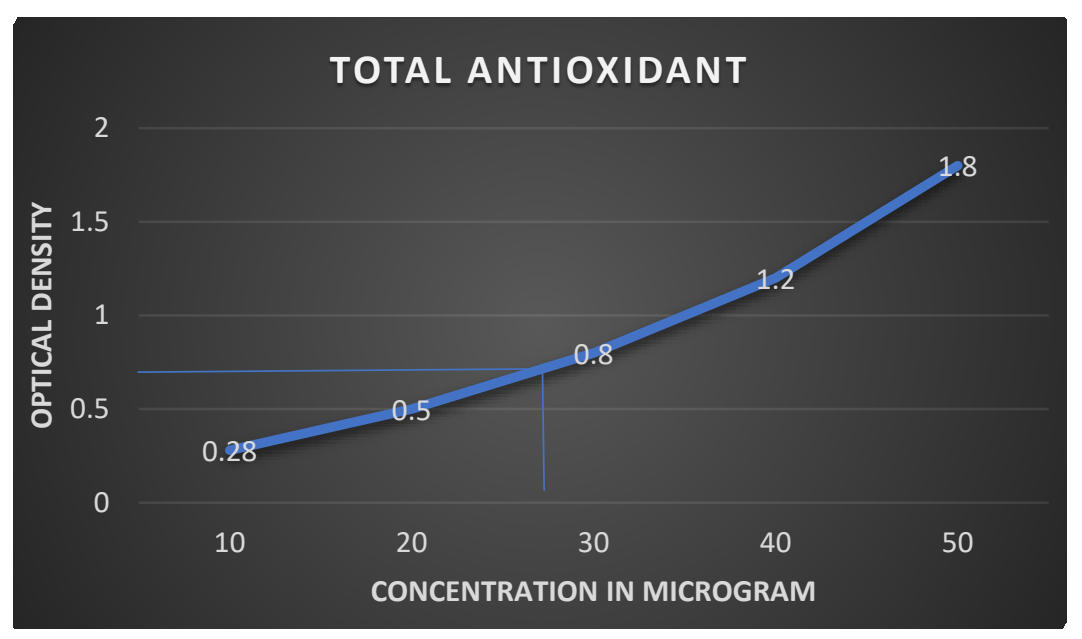


DPPH assay

The present study shows that the DPPH activity of hydroethanolic bud extract of Camellia sinensis was found $66.3 \mu \mathrm{g} / \mathrm{g}$ at a concentration of $500 \mu \mathrm{g} / \mathrm{ml}$.

Figure 3: DPPH assay

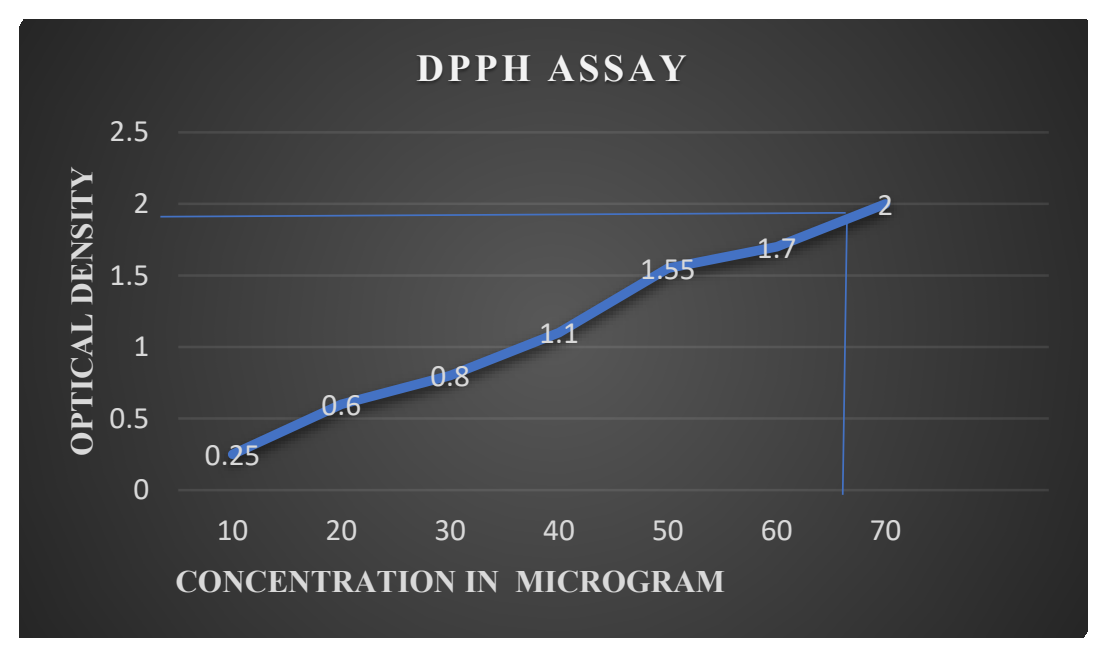

Rohadi et al.,2018 observed the antioxidant capacity of dried white tea (Camelia Sinensis) Extract compared to green, oolong and black tea. The results showed that the significant differences in the radical scavenging DPPH among samples $(\mathrm{p}<0.05)$. The highest radical scavenging was $93.61 \%$ obtained on the white tea extract $(1500 \mu \mathrm{g} / \mathrm{ml})$, then the lowest was $72.07 \%$ on the black tea extract.[23] FRAP assay

The FRAP assay hydroethanolic bud extract of Camellia sinensis was found $240 \mu \mathrm{g} / \mathrm{g}$ at a concentration of $1000 \mu \mathrm{g} / \mathrm{ml}$

Figure 4: FRAP assay

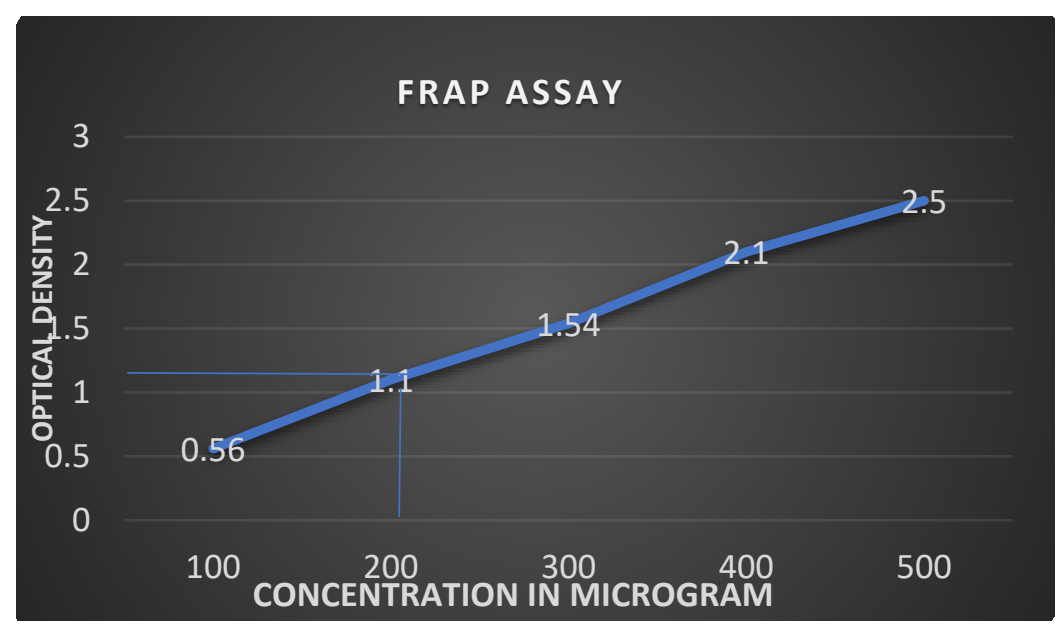


Shagufta et al.,2015 determined the antioxidant activity of crude methanol extracts (Murraya koenigii (curry leaves), Laurus nobilis (bay leaves), and Camellia sinensis (green and black tea powder) including DPPH, FRAP, and ICA. The results showed that C.sinensis (green) exhibited the highest antioxidant potential whereas M. koenigji showed the lowest $(C$. sinesis (green) $>$ (black) $>L$. nobilis $>M$. koenigji). The numerical values obtained for $C$. sinensis (green and black), L. nobilis, and M. koenigji were $<20 \mathrm{mg} / 100 \mu \mathrm{l}, 20-30 \mu \mathrm{g} / 100 \mu \mathrm{l}, 150 \mathrm{mg} / 100 \mu \mathrm{l}$ respectively.[24]

In vitro anti - inflammatory activity

The anti-inflammatory activity of Camellia sinensis bud extract was determined using protein denaturation and trypsin methods. The results were represented in table 3 and figure 4

Table 3: Anti-inflammatory activity in $C$. sinensis bud extract

\begin{tabular}{|c|c|}
\hline TEST & PERCENTAGE $(\%)$ OF \\
& INHIBITION \\
\hline Trypsin inhibition & 42.1 \\
\hline Protein denaturation & 43.5 \\
\hline
\end{tabular}

Figure 5: Anti-inflammatory activity in $C$. sinensis bud extract.

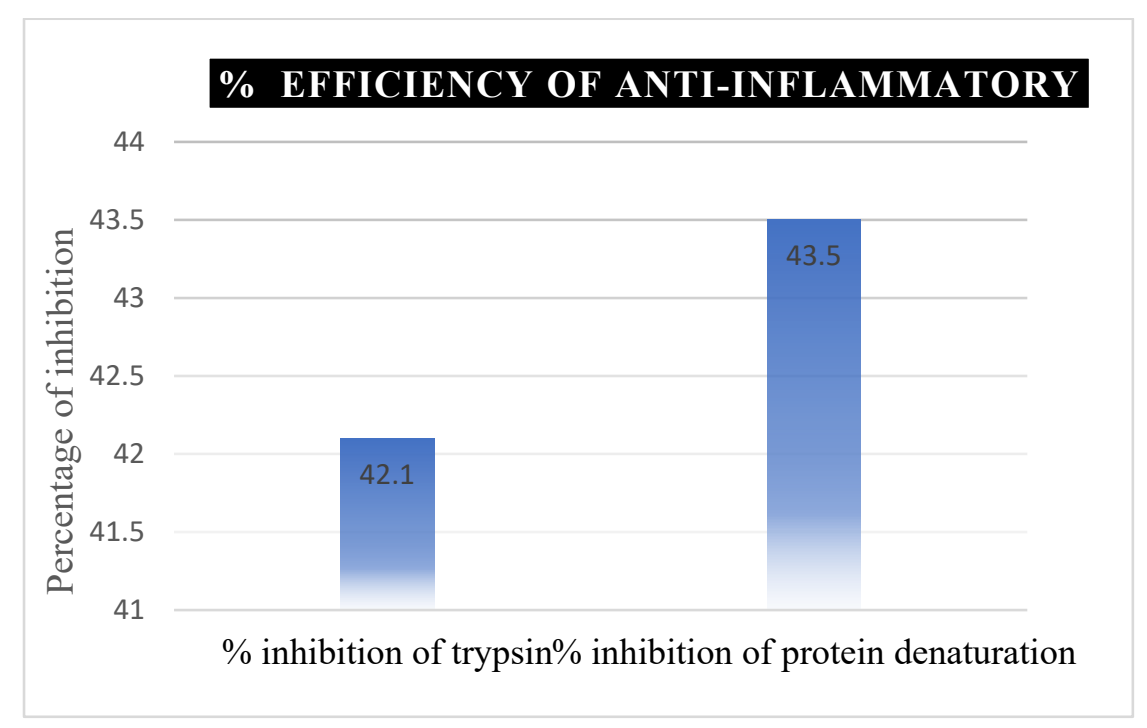

The present investigation of anti-inflammatory activity of Camellia sinensis bud extract using protein denaturation and trypsin methods revealed that the extract has significant anti -inflammatory potential against protein denaturation when compared to inhibition of trypsin.

Singh et al.,2019 revealed that the investigation of protein denaturation analysis of C.sinensis dried green tea extract has higher percentage of inhibition and significant anti-inflammatory activity 
compared to Hibiscus rosa sinensis, Matricaria chamomilla, Rosa sp and Zingiber officinale tea extract.[25]

\section{Summary and Conclusion}

White tea (Camellia sinensis) was used as medicine for various diseases. It is shown to have many biological properties like Phytochemicals, Anti-oxidant, Anti-inflammatory, Anticancer, Antifungal activity, Antimicrobial activity and Other biological activities. The present study showed that Camellia sinensis bud extract has significant antioxidant and anti-inflammatory activity. This activities in the extract are may be due to the presence of phytochemicals such as alkaloids, flavonoids, phenols, tannins and saponins. The present study results indicate that white tea can be used as an effective therapeutic agent against various diseases. Further study can be done to isolate compound responsible for anti-oxidant and anti-inflammatory properties.

\section{Acknowledgement}

The authors are grateful to Department of Biochemistry, Sri Ramakrishna College of Arts and Science for women Coimbatore, Botanical Survey of India Coimbatore and Centre for Bioscience and Nanoscience Research for providing necessary assistance.

\section{Reference}

1. Khalid S, Shahzad A, Basharat N, Abubakar M, Anwar P (2018) Phytochemical Screening and Analysis of Selected Medicinal Plants in Gujrat. J Phytochemistry Biochem 2: 108.

2. Yadav R, Khare RK, Singhal A (2017) Qualitative Phytochemical Screening of Some Selected Medicinal Plants of Shivpuri District (MP). Int J Life Sci Scientific Res 3: 844-847.

3. Patel Chirag J, Satyanand Tyagi, Nirmala Halligudi, Jaya Yadav, Sachchidanand Pathak, Satya Prakash Singh, Ashish Pandey, Darshan Singh Kamboj, Pratap Shankar Antioxidant activity of herbal plant. Journal of Drug Discovery and Therapeutics 1 (8) 2013, 01-08

4. Nemanja Stankovi ca, Tatjana Mihajilov-Krstevb, Bojan Zlatkovi cb, Vesna Stankov-Jovanovi cb, Violeta Miti cb, Jovana Jovi cb, Ljiljana Comi cc, Branislava Koci cd, Nirit Bernstein Antibacterial and Antioxidant Activity of Traditional Medicinal Plants from the Balkan Peninsula. NJAS - Wageningen Journal of Life Sciences 78 (2016) 21

5. Verma S. Medicinal plants with anti-inflammatory activity. J Phytopharmacol 2016;5(4):157159.

6. Priyal Inamdar, Jelamvazir, Sharav desai, Dhara patel, Dhananjay meshram phytochemical screening and in vitro antifungal activity of Camellia sinensis. International Journal of Pharmacy and Pharmaceutical Sciences ISSN- 0975-1491 Vol 6, Issue 5, 2014

7. Ganatra SH, Durge SP and Ramteke AM: Phytochemical's investigation and TLC analysis of Jasminum multiflorum leaves. Int J Pharm Sci Res 2013; 4(3); 1135-1139. 
8. Wadood A, Ghufran M, Jamal SB, Naeem M, Khan A, et al. (2013) Phytochemical Analysis of Medicinal Plants Occurring in Local Area of Mardan. Biochem Anal Biochem 2: 144. doi: 10.4172/2161-1009.1000144

9. Chede P. S Phytochemical Analysis of Citrus sinensis Pulp. International Journal of Pharmacognosy and Phytochemical Research 2012-13; 4(4); 221-223

10. Monika gupta, Shweta thakur, Anuradha sharma and Sudhakar gupta Qualitative and Quantitative Analysis of Phytochemicals and Pharmacological Value of Some Dye Yielding medicinal plants ISSN: 0970-020 2013, Vol. 29, No. (2); Pg. 475-481

11. Thilagavathi.T, Arvindganth.R Vidhya.D and Dhivya. R Preliminary phytochemical screening of different solvent mediated medicinal plant extract evaluated. International research journal of pharmacy $2015,6(4)$

12. Rahman Gul, Syed Umer Jan. Syed Faridullah, Samiullah Sherani and Nusrat Jahan Preliminary phytochemical screening, quantitative analysis of alkaloids and anti-oxidant activity of crude plant extract from Ephedra intermedia indigenous to Balochistan. The scientific world journal,2017 doi: https://doi.org/10.1155/2017/5873648

13. Belinda Nasike Siangu, Swaleh Sauda, Mwonjoria Kingori John and Wilson Mbiti Njue1 Antioxidant activity, total phenolic and flavonoid content of selected Kenyan medicinal plants, sea algae and medicinal wild mushrooms African Journal of Pure and Applied Chemistry Vol. 13(3), pp. 43-48, March 2019 DOI: 10.5897/AJPAC2018.0775

14. Nagaraju Bandaru, Y. Kranthi, K.Prasad, K.Chandrasekhar Evaluation of anti-cataract genic activity of of Biophytum Reinwardtii on olanzapine induced cataract on isolated goat lens /J. Pharm. Sci. \& Res. Vol. 11(6), 2019, 2121-2126

15. Naima Saeed, Muhammad R Khan \& Maria Shabbir Antioxidant activity, total phenolic and total flavonoid contents of whole plant extracts Torilis leptophylla $\mathrm{L}$ Article number: 221 (2012)

16. Tajner-Czopek, A. Gertchen, M. Rytel, E. Kita, A. Kochanski, A.Z. Sokół-Łętowska, A. Study of Antioxidant Activity of Some Medicinal Plants Having High Content of Caffeic Acid Derivatives. Antioxidants 2020, 9, 412. https://doi.org/10.3390/antiox9050412

17. M.H. Labiad, H. Harhar, A. Ghanimi, M. Tabyaoui Phytochemical Screening and Antioxidant Activity of Moroccan Thymus satureioïdes Extracts JMES, 2017 Volume 8, Issue 6, Page 21322139

18. Patel SS and Zaveri MN: Trypsin and Protein Denaturation Inhibitory Activity of Different Fractionation and Isolated Compound of Leaf and Root of Justicia Gendarussa. Int J Pharm Sci Res 2014; 5(12): 5564-71.doi: 10.13040/IJPSR.0975-8232.5 (12).5564-71

19. Deepthi K, Abhishek Kumar, Jennifer Fernandes and Deepthi D. Kodical Evaluation of in vitro anti-inflammatory activity of fruit extracts of spondias mombin Volume 20 No. 2, 2020 pp. 7905-7908 
20. Ibrahim Bashiru, Aminu. Umar, Catherine A. Otitolaiye and Sumayya A. Ayuba Phytochemical Screening, Proximate Analysis and Antioxidant Vitamins of Green Tea (Camellia sinensis) Leaves Consumed in Sokoto Metropolis, Sokoto-State, Nigeria Caliphate Journal of Science \& Technology (CaJoST) CaJoST, 2020, 1, 1-5

21. Amandeep Kaur, Sumaya Farooq, Amit Sehgal A Comparative Study of Antioxidant Potential and Phenolic Content in White (Silver Needle), Green and Black Tea Journal Name: Current Nutrition \& Food Science Volume 15, Issue 4, 2019

22. Raksha.K, Roshini.TJ, Chandra Prabha.D, Dhinek.A, Optimization of the Extraction of Polyphenols from Green Tea (Camellia sinensis), International Journal of Life Sciences Research, Vol. 5, Issue 1, pp: (37-43),2017

23. Rohadi1, Lelita D, A S Putri Antioxidant Capacity of White Tea (Camelia Sinensis) Extract: Compared to Green, Oolong and Black Tea IOP Conf. Series: Earth and Environmental Science 292 (2019) 012018 IOP Publishing doi:10.1088/1755-1315/292/1/012018

24. Shagufta Ishtiaque, Shahina Naz, Noorullah Soomro, Kehkashan Khan, Rahmanullah Siddiqui antioxidant activity and total phenolics content of extracts From Murraya koenigii (curry leaves), Laurus nobilis (bay leaves), And Camellia sinensis (tea) quaid-e-awam university research journal of engineering, science \& technology, volume 14, no.2, july-dec. 2015

25. Singh KG, Sonia S and Konsoor N: In-vitro and ex-vivo studies on the antioxidant, antiinflammatory and antiarthritic properties of Camellia sinensis, Hibiscus rosa sinensis, Matricaria chamomilla, Rosa sp., Zingiber officinale tea extracts. Int J Pharm Sci \& Res 2018; 9(8): 3543-51. doi: 10.13040/IJPSR.0975-8232.9(8).3543-51 